\title{
Humanitarian Measurement of International Relations Between Russia and Ecuador
}

\author{
Alla Borzova \\ Department of Theory and History of International \\ Relations \\ Peoples' Friendship University of Russia \\ Moscow, Russia \\ E-mail: borzova_ayu@rudn.university
}

\author{
Xavier Medina Gonzalez Vinicio \\ Department of Theory and History of International \\ Relations \\ Peoples' Friendship University of Russia \\ Moscow, Russia \\ E-mail: xaviervmg@gmail.com
}

\begin{abstract}
The article analyzes the relationship between the Republic of Ecuador and the Russian Federation in the humanitarian and cultural sphere. The main attention is paid to the educational sphere. The article tracks a process of establishing partnerships between representatives of the higher education system of the Federation Russia and Ecuador. Peoples' Friendship University of Russia (PFUR) is the vanguard of international education in Russia, and has the important role in the training of competitive specialists from Latin America and the Caribbean, in particular, from Ecuador.
\end{abstract}

Keywords-internationalization; Latin America; ecuador; RUDN University; PFUR University; cooperation; higher education; competitiveness; development; student

\section{INTRODUCTION}

In the modern world, where the acceleration of scientific and technological progress and the rapid introduction of scientific achievements in the production process have a decisive impact on the economic potential of the state, quality education and training of competitive professionals are becoming increasingly important. The University is intended to form social and human capital, as the level of University education and research is closely linked with the development of the country's economy [1].

Continuous improvement in the system of higher education not only contributes to the development of human potential, but also provides the country with a worthy role in the market of educational services, contributes to the formation of a positive image of the state on the world stage. Internationalization of education is becoming one of the important factors in promoting the country's interests in the global market of educational services and the development of international cooperation in this area [2].

International cooperation in the field of higher education and science, the spread of their language and culture have become an integral part of the policy of "soft power" as one of the key components of the state's influence on the international environment. It allows one to supplement the limited potential in the military-political and economic field and to form long-term channels of influence on partners. "The power of "soft" power (soft power)... acts in such a way that the subject freely and voluntarily submits to it, perceives its instructions as a result of his free choice" [3].

The foreign policy Concept of the Russian Federation approved by the President of the country V. V. Putin on 30.11.2016, States: "the use of soft power tools for solving foreign policy problems becomes an Integral part of modern international policy"[4]. We are talking about a comprehensive set of tools for solving foreign policy problems based on the capabilities of civil society, information and communication and other alternative classical diplomacy methods and technologies.

The peoples Friendship University of Russia (PFUR) plays an important role in the implementation of the concept of "soft power", adequately representing the country in the image of modern education in different countries of the world, including in the countries of Latin - Caribbean America.

\section{PFUR AND LATINO-CARIBBEAN AMERICA}

In early 1990s, The People's Friendship University was not going through the easiest of times. The University Board has relied on students from the Commonwealth of Independent States (CIS) and the increase in the number of paid places. The percentage of foreigners in the PFUR, and in the entire system of Russian education has fallen markedly and has not yet reached the level of Soviet times. The first issue of PFUR in 1965 consisted of $83.6 \%$ of foreign students (and $16.4 \%$ of Soviet students). After 44 years, the figures became almost diametrically opposite: in 2009, $79.4 \%$ of students from the CIS were enrolled in PFUR, and $20.6 \%$ were foreign students [5].

The percentage of Latin American students also declined. If in Soviet times it was about $19 \%$ of all foreign students, in Russia 2000, it decreased exactly 2 times [5].

Also, the personnel balance has shifted: while in Soviet times the majority of students from Latin America received education in engineering, now a significant part of such students in the PFUR study Humanities. The almost threefold decrease in agronomists is probably due to the fact that at the turn of the century a number of Latin American countries moved from an economy dominated by the 
agricultural sector to an economy dominated by industrial sectors (extraction of raw materials, etc.).

From 2013, we can talk about the renewed interest of Latin American students to get education in the PFUR, which is associated both with the improvement of the overall situation in the country, and with the thought-out policy of the PFUR on the internationalization of education and improvement of its system. This was reflected in the opening of new attractive specialties, optimization of Russian language study at the faculty of Russian language and General disciplines, improvement of the material and technical base of the University and living conditions in the campus; and the opening of master's and postgraduate courses in English.

PFUR was characterized by serious cooperation in the field of higher education with universities of other countries, the involvement of foreign teachers, conducting inter University student scientific conferences and round tables, the development of joint research projects with the enterprises of the country, and the expansion of the production base for practical training of students.

\section{PFUR AND ECUADOR}

Ecuador has been interested in cooperation with Russia our since the Soviet Union, when the two States exchanged students and researchers, and drew conclusions about the education system. At the moment, the relations between the two countries in the field of education have reached a qualitatively new level: the exchange of scientific experience and training system is implemented between several universities, where the PFUR plays a leading role.

With the intensification of cooperation in the field of education between the University and a number of universities in Ecuador were signed important documents, such as Agreements between the University and the Central University of Quito (1970), the University of Guayaquil (1983), Higher military Polytechnic school and the Catholic University in Quito (1994), technical University of Machala (1995), agricultural University of Ecuador (2009) [6]. Treaties signed with the people's Friendship University Technological University of Equinoxes (2013), National University of Loja (2015), National polytechnic school (2016) pursuing objectives such as the exchange of students and teachers, and organizational experiences in education programs [7].

Ecuador's great interest in the development of cooperation with PFUR in the field of science and education is due to the fact that from 2008 the country began to implement the "national plan for a good life" to develop the social structure and improve the living conditions of the population. In this regard, an important role is given to the improvement of the education and training system [8]. From 2006 to 2011 alone, the volume of funding for Ecuadorian education increased more than eight times (financial measures were aimed at increasing the size of scholarships and expanding access to educational loans), and the availability of secondary and higher education for all ethnic groups increased. In 2006-2011, access to education for the
Indian population increased by $22 \%$ and for the Afro Ecuadorian population by $14 \%$. It is worth mentioning the expansion of free access to public higher education and the increase in funding for education by 8 times during this period [9]. In the "National plan for a good life" for 20132017 it is planned to allocate $\$ 8,246$ million dollars for the development of science and human potential for social development — \$ 6984 million dollars [10].

In Ecuador, a real social revolution has taken place in recent years, and the profound reforms have made education more accessible and of better quality, and have provided access to the Internet for the majority of the population [11]. The Ecuadorian state had also closed a number of inefficient universities and had launched a large - scale project to establish the Yachai Institute of technology (Yachay City of Knowledge), which has to become a centre for technical applied research in Latin America. By the beginning of 2015, about \$ 600 million had been spent on the Yachai project and the whole "city of knowledge" will cost approximately \$20 billion dollars which is unprecedented for the region [12].

The concept of the Yachai project was developed in 2012-2013 by a group of internationally recognized scientists in close cooperation with the Ministry of science and technology of Ecuador (SENESCYT). Taking as a model the best research universities in the world, the Yachai project sets ambitious goals: to become the world's leading research University and the best scientific and technological University in Latin America; to attract world-renowned researchers through innovative and interdisciplinary research; to raise the educational level of citizens for the development of new technologies, economy, entrepreneurship, culture in Ecuador and Latin America; and to provide public services for the development of Ecuador's numerous ethnic communities.

To date, the construction of "Yachay" is not complete yet, but it is already doing research, published more than 100 scientific papers.

The government of Ecuador aims to provide access to the Internet in $90 \%$ of educational institutions, to reach $95 \%$ of the population aged 16 to 24 years of General secondary education and says that $80 \%$ of students must obtain diplomas within the prescribed time frame [13].

In the" National plan for a good life", quality education is not just a goal, but a continuous process for the development of human potential [14]. That is why Ecuador chooses for its country the best elements of the educational systems of those universities that are world famous. In this regard, PFUR has a brilliant reputation in terms of training foreign students in both language and profile programs, which has been proven over 58 years of work of the University.

Over the years of its existence, the People's Friendship University of Russia has trained more than 460 students and postgraduates from Ecuador [5].

PFUR plays a strategic role in relations between Russia and Ecuador in terms of training, which is reflected in the numerous visits of Ecuadorian government officials to PFUR. Thus, on October 30, 2009, President Rafael Correa Delgado 
visited PFUR for the first time. During the visit, he paid special attention to the fact that Ecuadorian University students are unoccupied after graduation. The President urged them to work actively to transform the country [15].

Four years later, Rafael Correa Delgado repeated his visit to PFUR. This time, the President of Ecuador discussed with the rector of the University V. M. Filippov the issues of training, as well as cooperation in science and culture. The President addressed the students with a speech on social justice and genuine democracy, after which he received the title of Honorary doctor of PFUR.

In December 01, 2015, People's Friendship University was visited by the Minister-coordinator of the Institute for the development of human talent (Instituto de Fomento al Talento Humano) Andrés Aros. In his speech, he touched upon the importance of the agreements concluded between the University and Ecuador, and outlined the prospects for their expansion.[16]

On 30 March 2016, Gabriela Rivadeneira, Chairman of the national Assembly of the Republic of Ecuador, arrived at the PFUR. She noted that "the PFUR erases all borders, allows young people from 150 countries to interact with each other and gives the opportunity to improve not only in the study of academic Sciences and technologies, but also in the best human qualities[17]. During the event, an agreement was reached to increase the number of students from Ecuador to PFUR. Also, those who are driving can enjoy the control Centre of space flights.

The tangible result of the four visits was an increase in the number of students from Ecuador to the PFUR. The Ecuadorian in the PFUR students are united in an Association which exists since 1968, the objectives of this organization is to help their fellow citizens in all spheres of accomplishment and fulfillment. Association of Ecuadorian students of PFUR monitors the maintenance of discipline, order, and also organizes cultural, sporting and entertainment events. A special role in the Association is played by the academic Secretary, who monitors the progress of students, the Secretary for sports, responsible for organizing sports events, and the Secretary for culture, planning dance, art and music events. In fact, Ecuador is actively working alumni Association People's Friendship University and other Russian universities. Graduates of Russian universities work in various sectors of the public and private sectors for the benefit of Ecuador.

The financial aspect of education of Ecuadorian citizens in the Russian Federation deserves special mention. Educational programs of Russian universities for foreign citizens include places paid by the Russian government from the Federal budget. The Federal Agency for CIS Affairs, compatriots living abroad and international humanitarian cooperation (Rossotrudnichestvo) organizes business contacts between universities in Russia and other countries. Students and graduate students from Ecuador money for training and all related costs are allocated not only from the budget of Russia. The government of this Latin American country considers the scholarship received by the students of the PFUR to be insufficient. In order to improve the situation, the government of Ecuador has developed a programme entitled "Additional scholarship for international cooperation" at the Institute for the development of human talent. Additional scholarship programs within the framework of international cooperation have become part of the national scholarship program and are designed for students who wish to study in Brazil, Slovakia, Russia, Venezuela and Cuba. The program is aimed at additional funding for scholars from Ecuador to successfully complete their studies abroad.

President of Ecuador Lenin Moreno, who came to power in May 2017, maintained the educational course taken by the "Civil revolution", where the state has an important role in the development of the education system [18]. He announced the expansion of scholarship support for students, the development of contacts between universities and the manufacturing sector. The" national development Plan for 2017-2021 "noted the desire to increase the number of public libraries in Ecuador, to expand the information network in order to reduce the gap in Internet access between different segments of the population, to develop not only technical but also humanitarian education, as well as education in the arts [19].

\section{CONCLUSION}

In modern conditions, when the elements of "soft power" are becoming increasingly important in shaping the image of the state, the Russian Federation must demonstrate its advanced achievements in the field of science and education, expand cultural cooperation. PFUR plays the role of the avant-garde in the process of internationalization of education, and is constantly improving the system of teaching in the process of training qualified personnel for many countries, including Latin America. The analysis of the contingent of Latin American students of the University leads to the conclusion that the education offered by the University is in demand in Latin America, and students are increasingly seeking to continue their education after receiving a bachelor's and master's degree.

For Ecuador, one of the small countries in the region, cooperation with the PFUR in training has serious prospects. In recent years, the number of Ecuadorian citizens studying at the PFUR has steadily increased. And the first persons of the Latin American state who visited PFUR only confirmed the correctness of the current vector of Russian-Ecuadorian relations and the role played by the University in strengthening bilateral relations.

\section{REFERENCES}

[1] Koldunova E.V., Lounev S.I. The processes of transformation of the education system and science in Asia in the estimates of international organizations and transnational ranking agencies. Vestnik RUDN. International Relations. 2017. №1, pp.190-200.

[2] Filippov V.M. Internationalization of Higher Education: Major Trends, Challenges and Prospects. Vestnik RUDN. International Relations. 2015. №3, pp. 203-211.

[3] Rusakova O.F. The concept of "soft power" in modern political philosophy. Scientific Yearbook of the Institute of Philosophy and 
Law of the Ural Branch of the Russian Academy of Sciences. 2010. № 10, pp.173-192.

[4] Foreign Policy Concept of the Russian Federation (approved by President of the Russian Federation Vladimir Putin on November 30, 2016) // Ministry of Foreign Affairs of the Russian Federation.URL: http://www.mid.ru/foreign_policy/news//asset_publisher/cKNonkJE0 2Bw/content/id/2542248 (accessed: 25.11.17).

[5] Volosyuk O.V., Marchuk, N.N. PFUR and Latin America - 50 years of cooperation. Moscow: RUDN. 2009, pp. 37-71.

[6] Borzova A.Y., Volosyuk O.V. 50 Years of Collaboration: Peoples' Friendship University of Russia and the Universities of Latin America. RUDN Journal of World History.2009. №2, pp. 93-100.

[7] The base UIS (Unit Informative System) (PFUR) 01.04.2017.

[8] Ponce J., Loyaza Y. Elimination of User-fees in Tertiary Education: A Distributive Analysis for Ecuador. International Journal of Higher Education. 2012, № 1, pp.138-147.

[9] Savala P.A.C. Landmarks and achievements of the "Decent Life" plan. Latin America, 2014, №3, pp. 56-74.

[10] National Plan /Good living - a better world for everyone 2013- 2017 //Quito. Ecuador. URL: http://www.buenvivir.gob.ec/ (accessed: 02.01.2018).

[11] Davydov V.M. (Ed.) Ecuador on the road to the "Civil Revolution". Moscow: ILA of RAS. 2009, p.77.

[12] Yachay Tech Universidad. URL: https://www.yachaytech.edu.ec/en/about/history/ (accessed: 27.05.17).

[13] National Plan /Good living - a better world for everyone 2013- 2017. URL: http://www.planificacion.gob.ec/wpcontent/uploads/downloads/2017/ 10/PNBV-26-OCT-FINAL_0K.compressed1.pdf (accessed: 25.11.17).

[14] Savala P.A.C. Landmarks and achievements of the "Decent Life" plan. Latin America.2014, №3, pp.56-74.

[15] For me, going back to university is like meeting yourself again. // Druzhba. 09.11.2009, № 20. URL: http://www.rudn.ru/?pagec=2247 (accessed: 26.05.17).

[16] Visita a Rusia de Ministro Coordinador del Conocimiento y Talento Humano.

[17] Visit to Russia as Coordinating Minister of Knowledge and Human Talent. URL: http://rusia.embajada.gob.ec/tag/urap-andres-arauz (accessed: 26.05.17).

[18] Visit to PFUR of the President of the National Assembly of the Republic of Ecuador, Gabriela Rivadenira. URL: https://www.youtube.com/watch?v=WGjFw-Sb4hw (accessed: 26.05.17).

[19] Pyatakov A.N. The victory of Lenin Moreno in Ecuador. Latin America. 2017. №6, pp.17-27.

[20] Plan Nacional de Desarrollo 2017-2021. Toda una Vida. Secretaría Nacional de Planificación y Desarrollo Senplades 2017 Quito Ecuador.

[21] National Development Plan 2017-2021. Whole Life. National Secretariat of Planning and Development Senplades. 2017 Quito Ecuador.

http://www.planificacion.gob.ec/wpcontent/uploads/downloads/2017/ 10/PNBV-26-OCT-FINAL_0K.compressed1.pdf (accessed: 25.11.17). 